\title{
WITTGENSTEIN'S TREATMENT OF SOLIPSISM IN THE TRACTATUS
}

It would be difficult to feel confident in the completeness of an interpretation of Tractatus 5.6-5.641. For Wittgenstein's remarks in this enigmatic passage have a certain richness, which gives them the possibility of development in more than one direction. Their connections with Schopenhauer's ideas about solipsism, explored by P. M. S. Hacker in Insight and Illusion (Ch. III), do not always make them easier to understand. How much does Wittgenstein's use of Schopenhauer's words commit him to acceptance of his ideas? Does the critique of solipsism in the Tractatus depend on the treatment of the will, which comes later in the book? These are difficult questions of interpretation, and I shall not attempt a full answer to them in this paper. Instead, I shall select a series of connected points which Wittgenstein makes prominently. There may well be other, equally interesting points in the background of his discussion, especially when it is read together with the remarks in the Notebooks that were not repeated in the Tractatus. I make no claim to the completeness of my interpretation, but I hope to show that there is a strong, independent and original argument linking the points that I select.

First, a rough classification of the various types of solipsism is needed. In general, the solipsist says that the things that exist are all related to his own experience. This, of course, is dogmatic solipsism, and there are waker versions of the thesis. There are also two further dimensions of possible variation. One variant is the reference point that 
is chosen: "experience" is a vague word, and the reference point might be the solipsist's immediate field of consciousness, or, alternatively, it might be the ego to which that field is supposed to be presented. The second variant is the relation between the reference point and the only things to which the solipsist concedes existence: the relation might be identity - i.e. the thesis might be that the only things that exist are the contents of the immediate field, identified in either of the two ways that have just been distinguished -or, alternatively, the relation might be more remote, so that the basis would be broader-e.g. things recollected might also be allowed to have existed, or perhaps the thesis might be even more liberal and let in things which could be recollected. There is, however, an absolute limit to the liberalisation of the theory: the privileged basis cannot include any things which would not be accessible in any direct way. All these versions of solipsism face an inconspicuous but formidable problem: How is the reference point itself identified?

There is one more dimension of variation that needs to be mentioned before Wittgenstein's remarks are examined. The restriction put by the solipsist on the things that exist has two distinct consequences. It limits knowledge of truths, and it limits understanding of meanings. Traditional solipsism emphasises the first of these two consequences, and so-called "linguistic solipsism" emphases the second.

Wittgenstein's treatment of this topic in the Tractatus has four striking features:

i. It is an investigation of the subject-self, or ego.

ii. It explores the consequences of the fact that the ego is not an object of experience.

iii. It is especially concerned with the consequences for linguistic solipsism.

iv. The outcome of the investigation is that the linguistic solipsist is making a good point, but making it in the wrong way, because he is trying to say what can only be shown. 
It can hardly be an accident that the last three points can be read as a criticism of the account of the ego which Russell gave in "On the Nature of Acquaintance". This work of Russell's was published as three articles in the Monist in 1914 and 1915, and they have been reprinted by $R$. C. Marsh in Essays in Logic and Knowledge. But the articles are, in fact, the opening chapters of a book, Theory of Knowledge which Wittgenstein is known to have read and criticised severely in 1913 and which Russell never published in its entirety. So it might be useful to sketch in Russell's 1913 theory of the ego as part of the background of the Tractatus, without, of course, implying that there is no debt to Schopenhauer. Hacker makes the plausible conjecture that Wittgenstein re-read Schopenhauer's The World as Will and as Idea while he was writing the last of the three surviving notebooks (loc. cit. p. 64). What I am adding is that Russell's 1913 ideas were still vivid in his mind, the latest and one of the clearest examples of a crucial error.

Russell's treatment of self-knowledge in "On the Nature of Acquaintance" is entirely concerned with the ego. He points out that the theory of the ego has nothing to do with the problem of personal identity (Logic and Knowledge, p. 163). For this problem can be solved only through an examination of the contents of a mind (loc. cit. pp. 136-7), and the Ego is not among the contents of a mind (loc. cit. p. 164). Here he is retracting his earlier view, maintained with some hesitation, that the ego is an object of acquaintance (The Problems of Philosophy, p. 50). He has been convinced by Hume's criticisms of that kind of theory.

So far Wittgenstein's discussion runs roughly parallel. In the Tractatus there is the same focus on to the problem of the ego, and the same insistence that it is not an object of experience (5.631 ff.). This Humean point is, of course, entirely compatible with the empirical accesibility of the composite self studied by psychology $(5.5421,5.631,5.641$ : see 
Hacker loc. cit. pp. 62-3). But Wittgenstein disagrees with what Russell says next. For Russell's next step is to argue that the ego is known only by description (Logic and Knowledge, p. 162-3), and, according to Wittgenstein, this is based on a misunderstanding of the consequences of the fact that the ego is not an object of experience.

It might be useful to look at the difficulties into which Russell's next step takes him. If the ego is known only by description, then, by the principles of Russell's empiricism, it ought to be either a logical construction out of things of some other type, or else sufficiently similar to some other type of thing with which we do have acquaintance. But Russell did not treat it in the first of these two ways until 1918 (see The Philosophy of Logical Atomism in Logic and Knowledge, p. 276), and the ego hardly meets the requirement of sufficient similarity to some other type of object of acquaintance, even when this requirement is interpreted loosely.

This leads to another, related, difficulty. If the concept of an ego is connected with experience in such a remote way, how was Russell to identify particular egos? In Knowledge by Acquaintance and Knowledge by Description he had suggested that " ' $\mathrm{I}$ ' means the subject-term in awareness of which $I$ am aware. But", he observes, "as a definition this cannot be regarded as a happy effort" (Mysticism and Logic, pp. 211-2). For, of course, it leads to an infinite regress. In On the Nature of Acquaintance, he tries to improve the theory by eliminating the second occurrence of "I", and so avoiding the degress. The improvement is to take the experience, which is, in fact, my present experience, as given, and to refer to it with a pure demonstrative lacking any connotation. "The subject attending to 'this' is called ' $I$ ', and the time of the things which have to ' $I$ ' the relation of presence is called 'the present time'. 'This' is the point from which the whole process starts, and 'this' itself is not defined, but simply given. The confusions and difficulties arise from regarding 'this' as defined by the fact of being 
given, rather than simply as given." (loc cit., p. 168).

This solution avoids the infinite regress, but the price that it pays is that any ego will be identifiable only in a way that makes its ownership of experiences necessary ownership. It is here that Wittgenstein attacks it, when he explores the consequences of the fact that the ego is not an object of experience (stage $i i$ in his treatment of solipsism in the Tractatus).

As for stage $i i i$, it is interesting to observe that, in "On the Nature of Acquaintance", Russell anticipates the linguistic version of solipsism that Wittgenstein uses in the Tractatus. He says: "Every word that we now understand must have a meaning which falls within our present experience; we can never point to an object and say: 'This lies outside my present experience'. We cannot known any particular thing unless it is part of present experience..." (at this point he reverts to traditional solipsism, which restricts knowledge of truths rather than understanding of meaning (loc. cit., p. 134). This is the precursor of Tractatus 5.61 : "We cannot say in logic, "The world has this in it, and this, but not that'. For that would appear to presuppose that we were excluding certain possibilities, and this cannot be the case, since it would require that logic should go beyond the limits of the world."

But Russell formulates linguistic solipsism only to reject it, whereas stage $i v$ of Wittgenstein's treatment is qualified acceptance of it. This is the final and most important difference between the two philosophers in this area. Russell argues for the existence of his own ego as if he were arguing for the existence of an object which he merely happened not to know by acquaintance. loc. cit., p. $163 \mathrm{ff}$.). This is a clear example of a metaphysical hypothesis masquerading as a scientific hypothesis. Similarly, he tries to refute solipsism by arguing that, as a matter of scientific fact, 'there are particular things which lie outside present experience" (loc. cit., pp. 134-5). Wittgenstein's treatment is 
entirely opposed to this procedure: neither the existence of the ego nor the truth of solipsism is an empirical matter for him. These are metaphysical questions which lie beyond the limit of what can be said, and, with this qualification, he accepts linguistic solipsism, unlike Russell, precisely because he takes a different view of the existence of the ego.

So Wittgenstein's treatment of solipsism may be regarded as (among other things) a critical continuation of Rusell's investigation of this topic. It begins with the same narrow focus on to the problem of the ego, uses the same linguistic version of solipsism and endorses Hume's argument against "an impression of the self" in the same way. Divergence and criticism begin at the point where Russell fails to see the consequences of the validity of Hume's argument.

The details of Wittgenstein's critical argument are notoriously difficult to interpret. Part of what he says is clear, and part is obscure. The clear part, which will be examined first, is the inference from the fact that the ego is not an object of experience, to the conclusion that it is a reference point which is not identifiable independently of whatever field of objects is being considered, and the further inference that, therefore, the apparently fierce restriction that solipsism puts on the things that exist is a sham. The obscure part is the implied specification of the field of objects that is being considered. Are they the objects that have been in, and are in, the field of consciousness of a particular person? Or is this restriction supposed to be abolished when the ego is revealed as an unusable reference point?

First, some account of the putatively restrictive force of linguistic solipsism is needed. If Russell had developed his version of the theory, he would have done so in two stages. First he would have said that the limit of the propositions that I can understand is fixed by my acquaintance with things. Here "acquaintance" is narrower than "experience" but not so narrow that it will not reach into my past, at least when its objects are qualities and 
relations. In fact, the theory must be liberalised to this extent, because my understanding of meanings could hardly be based exclusively on my contemporary objects of acquaintance. His second step in the development of the theory would have been to add that propositions which I cannot understand cannot be understood. The linguistic solipsist's justification of this step would be that nothing exists outside the circle of my acquaintance, so that the basis of all understandable propositions must be situated within that circle. The first of these two steps is simply an appeal to Russell's empiricist theory of meaning, but the second step, which is the more fiercely restrictive one, uses an argument which he did not regard as valid. In On the Nature of Acquaintance" he develops solipsism only to reject it on quasi-scientific grounds.

In this version of linguistic solipsism the restrictive mechanism clearly requires for its working a previous identification of a particular ego through the objects with which that ego is acquainted. The same is true of the version discussed by Wittgenstein in the Tractatus. However, there are differences between the two versions, because they are developed in the setting of two different theories of language, and two diferent ontologies. To ignore the differences between the two versions might discredit the sug. gestion that in the Tractatus Wittgenstein really has Russell's 1913 theory of the ego in mind. For if the similarity between the two versions of linguistic solipsism were exagerated, a natural reaction would be to discount it altogether. The truth is that the features shared by the two versions are all that is required for the continuity of the two philosophers' discussions of solipsism.

The strongest objection to this claim would be that Wittgenstein's objects are not objects of experience. This is true, and point $i i$ in the analysis of his discussion of solipsism in the Tractatus would be more accurately stated, "The ego is not an object". However, the reason why the objects of 
the Tractatus are not objects of experience needs to be explained. The reason is not that our cognitive relation with objects would not be acquaintance (T.L.P.2.0123). Nor is it that objects would turn out to be things of a kind that empiricists would not normally treat as basic (the illustrative examples used by Wittgenstein in the Notebooks, in the Tractatus and in his later comments on the theory make this quite clear). The reason is that, when he compiled the Tractatus he had not pushed the analysis of factural propositions far enough to be able to identify objects. Of course, he never did succeed in carrying out this programme. But this failure was hardly essential to his theory, and, while he still thought that he would succeed, he took over the apparatus of empiricism and set it up in a very speculative way at a level of analysis that he had not yet reached.

The result was not an empiricist theory of meaning. For the basis of that kind of theory has to be a familiar type of thing, or, at least, one that is already identified, and all factual propositions have to be constructed on that basis. But the first movement of Wittgenstein's thought was in the opposite direction, from odinary factual propositions to a totally unfamiliar basis, established by a transcendental linguistic argument (loc. cit. 5.562-3). Nevertheless, the objects of the Tractatus are suitable objects for acquaintance, and the second movement of his thought was to use them as a basis for constructing all factual propositions. So the range of objects fixes the limit of understandable propositions (loc. cit. 5.5561), and this is all that is required for the continuity of the discussions of solipsism in "On the Nature of Acquaintance" and the Tractatus.

When Wittgenstein endorses Hume's argument and draws the first consequence that undermines Russell's theory, he borrows a striking analogy from Schopenhauer (see Hacker loc. cit. pp. 64-5). "The subject does not belong to the world; rather, it is a limit of the world. Where in the world is a metaphysica subject to be found? You will say that 
this is exactly like the case of the eye and the visual field. But really you do not see the eye" (T.L.P. 5.632-3). This is Hume's argument. The first point against Russell's 1913 theory of the ego is made in the next sentence. "And nothing in the visual field allows you to infer that it is seen by an eye." This point is less obvious, and Wittgenstein argues for it in the immediate sequel, 5.6331 and 5.634: "Forthe form of the visual field is surely not like this" - -here he draws a picture of the visual field with an eye in its tapering root- "This is connected with the fact that no part of our experience is at the same time a priori. Whatever we see could be other than it is. Whatever we can describe at all could be other than it is. There is no $a$ priori order of things".

Taken as a point against Russell's 1913 theory of the ego this is clear enough. But it becomes less clear when it is taken as an indication "that solipsism, when its implications are followed out strictly, coincides with pure realism. The self of splipsism shrinks to a point without extension, and there remains the reality co-ordinated with it". (loc. cit. 5.64).

The point against Russell must be that in his theory the ego can be identified only through the field of its objects. It would have been all right if he had first identified it in that way, and then given a description of it which might be used as an independent method of identifying it. For in that case we would not have been forced to treat the statement that a certain field of objects is presented to a particular ego as the statement of an a priori truth. We could have extracted an independent method of identifying the ego from the further description of it, and so made the statement contingent. But there is no such possibility in Russell's theory. That door is shut when he says that the ego can be identified only through the field of its objects, and so can be known only by a description of the form "The ego acquainted with..." ("On the Nature of Acquaintance": loc. 
cit. p. $162 \mathrm{ff}$.). In effect, Wittgenstein is reminding Rusell of a common feature of their two theories of language. If a type of thing is introduced in the way that Russell introduces egos, then the correlation of egos with fields of objects cannot be established empirically.

It is important to see exactly how the analogy between ego and eye is supposed to work. Wittgenstein must be assuming that $I$ start by defining my eye as whatever takes in my visual field. But then I can discover by experiment which part of my body satisfies this definition. I cover the upper half of my face with my hands, and my visual field is switched off. So it is a contingent fact that my eye, identified as a particular part of my body, is the point of intake. Therefore, Wittgenstein must be excluding the possibility of this experiment from the analogy, and in fact the exclusion is justified. For when I carry out the experiment, I make certain assumptions about the identity and relative positions of various parts of my body, and about the propagation of light-rays and the dependence of seeing on light-rays, and his thesis is only that nothing in my visual field allows me to infer that it is taken in by an eye. Against Russell's 1913 theory it is enough to establish this thesis. For in that theory egos are tied by definition to fields of acquaintance, without any possibility of supplementary descriptions of them. So when Wittgenstein uses my present visual field as an analogue, it is perfectly fair for him to insist that, for the purposes of the analogy, I am not allowed to use anything outside my present visual field. Thus the analogy explains how Russell's inference forfeits its empirical character.

This brings me to the end of the interpretation of the clear part of what Wittgenstein says. Before I attempt to interpret the obscure transition to solipsism, there are two points that need to be emphasised. First, the suggestion that Wittgenstein's target was Russell's 1913 theory of the ego does not imply that he had no knowledge of other similar 
theories put forward by earlier philosophers. The point is only that Russell's theory was the latest example to hand, and that he is known to have read and disapproved of the book that contained it. The second point is that even in his argument against Russell he may well have other issues in mind. In the sequel I shall try to show that his transition to solipsism is made in the light of the difference between his theory of representation and Schopenhauer's. In fact, solipsism is the dominant issue in the Tractatus, and he pronounces on it first, and it is only his argument for his veridict on solipsism that begins with the theory of the ego.

The first step towards understanding the connection between Wittgenstein's treatment of the ego and his critique of solipsism is to establish what the $a$ priori truth alluded to in 5.6331 and 5.634 is. How exactly is the fact that the visual field is not as he sketches it connected with the fact that no part of our experience is at the same time $a$ priori? I have suggested that he is thinking of the statement that a certain field of objects is related to a particular ego in a potentially cognitive way (in Russell's simpler theory the relation would be presentation, which is the converse of acquaintance). This would be $a$ priori if the ego were identifiable only through its relation to this field. This interpretation is obviously required by the thesis that his main target was Russell's 1913 theory of the ego. But that, of course, is not enough to establish it. It needs to be established by an independent argument.

There are, in fact, two rival interpretations, and one way of arguing for mine would be to try to eliminate them. Both the rival interpretations are latent in Hacker's preliminary paraphrase of 5.634. "Whatever we see could be otherwise. But, by implication, that our experience belongs to us and could not belong to another is a priori. It could not happen that we should need to employ some principle of differentiation to distinguish within the flow of experience those experiences that belong to us from those that belong to others" 
(loc. cit. p. 63). I am not sure how the word "experience" is being used here, but it might be a collective noun for sense-data, images, etc. If so, the a priori statement, that your experiences belong to you and could not belong to another, might be based on the criteria of numerical identity of such phenomenological objects. Since yours cannot be shared by me, or transferred to me, I have no direct access to them, and this yields a familiar argument for traditional solipsism.

I am not attributing this interpretation to Hacker, although he does claim to see a connection between the solipsism approved by Wittgenstein in the Tractatus and phenomenologically based solipsism which I am unable to see. I mention the interpretation because it is natural to read this kind of solipsism into the Tractatus. But it is quite wrong. There are several objections to it, cumulatively conclusive. First and perhaps most weighty, is the evident fact that in the Tractatus Wittgenstein does not commit himself to the view that objects are phenomenological (or that they are not). Second, even if the treatment of solipsism were an isolated passage presupposing that they are phenomenological, there is no indication in the Tractatus of any route from phenomenologically based solipsism to realism, although 5.64 shows that there ought to be. Of course, an itinerary of this kind is given in some of the writings of his middle period (see Hacker: loc. cit. p. 187 ff.), but there does not seem to be sufficient evidence for reading it between the lines of the Tractatus (as Hacker does, loc. cit. p. 80-1). Third, the $a$ priori statement suggested by this interpretation is not particularly closely connected with the theory of the ego. It is equally relevant to a theory which treats the self as a logical construction without any residual subject. Fourth, this interpretation misses the relevance of Wittgenstein's theory of repressentation - a point which I shall expand later.

The second interpretation implicit in Hacker's paraphrase 
of 5.634 is much closer to the one for which I am arguing, but not quite the same. According to it, the $a$ priori statement would be that if I experience any object, then the experience of it is mine. It is a corollary of this that my ownership of the experience is not established by and feature of what I experience. This interpretation, unlike the other, is compatible with the thesis that the objects of the Tractatus are not phenomenological. It also fits Wittgenstein's remark that "whatever we see could be other than it is" (5.634). However, it still has one fault. It is an a priori truth that, if I experience any object, then the experience of it is mine, whatever I am. But this is an embarrassment only to the theory that I am a pure ego, identifiable only through "my" field of objects.

It is crucial that Wittgenstein's remark is directed exclusively against this theory. For in 5.64 he says that "the self of solipsism shrinks to a point without extension", and that it is because this happens that solipsism, when its implications are followed out strictly, coincides with pure realism". The same narrow focus is maintained in his explanation of this remark, which closes the discussion of solipsism in the Tractatus: "Thus there really is a sense in which philosophy can talk about the self in a non-psychological way. What brings the self into philosophy is the fact that "the world is my world". The philosophical self is not the human being, not the human body, nor the human soul with which psychology deals, but rather the metaphysical subject, the limit of the world - not a part of it" (5.641). But the interpretation under scrutiny, unlike the one for which I am arguing, ignores this narrow focus. Therefore, the later is preferable.

This argument by elimination needs to be reinforced. It is not enough that my interpretation reflects a feature of Wittgenstein's discussion which he evidently felt to be important. We need to understand why it was important for him to keep it focussed on to the theory of the ego, and the 
only way to understand this is to establish how he supposed the theory of the ego to be connected with solipsism.

Earlier in this paper I posed the question, how he intended the field of objects that "make up the substance of the world" (2.021) to be specified. I asked whether they are the objects that have been in, are in, the field of consciousness of a particular person, of whether this restriction is supposed to be abolished when the ego is revealed as a bogus reference point. This question may be reformulated in the light of some points already discussed. Are they the objects whose range fixes the limit of the propositions that are understandable to a particular person? Or is this restriction removed when the ego is discredited as a reference point? In this formulation the question is about linguistic solipsism rather than traditional solipsism, and it does not presuppose that the person is actually acquainted with the objects that underpin his language.

One step towards answering this question has already been taken. If Wittgenstein is not committed to the view that his objects are phenomenological, then he cannot mean to restrict the basic range of objects in any way that presupposes that view. In fact, the only way of restricting it that is envisaged in the Tractatus is quite different. The basic objects are the objects of "my world" (5.6). Now this specification of them will be genuinely restrictive only if it is accompanied by an identification of me. But in the Tractatus the self to which the solipsist appeals is always "the philosophical self" (5.641) or ego, which "does not belong to the world" (5.632). So surely Wittgenstein's thesis must be that solipsism is not genuinely restrictive, because it uses a useless reference point. I would not argue for this interpretation by quoting any of his later remarks which are not explicit comments on the Tractatus, but, if it is correct, it can be expressed in words used by him in the Blue Book: "When I made my solipsist statement, I pointed, but I robbed the pointing of its sense by insepa- 
rably connecting that which points and that to which it points. I constructed a clock with all its wheels, etc., and in the end fastened the dial to the pointer and made it go round with it. And in this way the solipsist's "Only this is seen" reminds us of a tautology" (p. 71).

This interpretation is confirmed by the Notebooks, which contains no suggestion of any other method of specifying the solipsist's objects. So it is not the case that Wittgenstein had several ways of developing the solipsist's case, and then selected one version of it for discussion in the Tractatus. It is particularly important that never in this period does he use the idea that the solipsist's objects are restricted in range because objects are a private type of thing. The whole treatment is compatible with realism.

At this point it might be useful to relate his discussion of solipsism to the more general aims of the Tractatus. Stage $i v$ in my preliminary analysis was that, according to him, the linguistic solipsist is making a good point, but making it in the wrong way, because he tries to say what can only be shown. What exactly is this thing that can only be shown? And why is it that it can only be shown? Answers to these questions might put his treatment of solipsism in its place in his system, and, when that has been done, the final details of the interpretation may be completed.

Several commentators have drawn attention to the importance of the context of the discussion of solipsism in the Tractatus. In $5.55 \mathrm{ff}$. Wittgenstein argues that we are unable "to answer $a$ priori the question about all the possible form of elementary propositions." But since their forms depend on objects (5.5561), this means that we are unable to determine the range of object $a$ priori. The only thing that "we know on partly logical grounds" is "that there must be elementary propositions." (5.5562), and so that there must be objects. Is it, then, an empirical matter that there are such and such objects in the world? We might be inclined to think so, because "Empirical reality is limited by the totality of 
objects" (5.5561). However, we would be wrong to regard the limitation as empirical, because the range of objects fixes the limit of understandable propositions, which is also the limit of the world (5.61). I can say that a matchbox contains this match and this one, but not that one. But this is because the limits of the receptacle are not fixed by its contents. If the world is a receptacle, it is not one that satisfies this condition. "So we cannot say in logic, "The world has this in it, and this, but not that'. For that would appear to presuppose that we were excluding certain possibilities, and this cannot be the case, since it would require that logic should go beyond the limits of the world; for only in that way could it view those limits from the other side as well. We cannot think what we cannot think; so what we cannot think we cannot say either" (5.61).

This crucial passage answers both my general questions of interpretation. The thing that can only shown is that there are such and such objects. The reason why it can only be shown is that it is not an empirical statement. It is presupposed by the existence of language. If it is a metaphysical conclusion, it is neither a quasi-scientific one nor an a priori one. Both these denials are directed at Russell.

Immediately after this crucial passage Wittgenstein says, "This remark provides the key to the problem, how much truth there is in solipsism" (5.62). But what exactly is the key? In the whole passage from 5.55 down to the end of 5.61 there has been only one, possibly restrictive, reference to "me". 5.6, on which 5.61 is a comment, says that, "The limits of my language mean the limits of my world", and it is possible that the phrase "This remark" refers back to 5.6. In any case, the key must be something that applies to language, and to my language in particular. Now the only thing in the text preceding $\mathbf{5 . 6 2}$ which it could possibly be is the thesis, that the contents of a receptacle can only be shown when it is impossible to give them empirically because they fix the limits of the receptacle. This thesis, 
which is stated in 5.61, applies to the relation between any set of objects and the world that it delimits. So it amplies both to the relation between my objects and my world and to the relation between "the totality of objects" (5.5561) and the world. Equally, it applies both to the relation between my objects and the only language that I understand, and to the relation between "the totality of objects" and language in general. This last application is based on the common features of Russell's and Wittgenstein's theories of language.

In the interpretation of this passage it is an extremely important fact that the key works only if my world is a receptacle with limits fixed by its contents. Now Wittgenstein considers only one alternative to regarding my world in this way, and that is regarding it as a world specified through an ego. However, at this point the stream of his reflections on Russell's 1913 theory of the ego joins the main stream of his discussion of solipsism, and he argues that the ego cannot be used as a reference point. The details of that argument have already been examined. Since it demolishes the only alternative way of specifying my world that Wittgenstein considers, it follows that for him my world is a receptacle with limits fixed by its contents.

So "the key to the problem, how much truth there is in solipsism" is the fact that both my world and the world are receptacles with limits fixed by their contents. From this it follows that their contents cannot be given empirically. Therefore, what they are can only be shown, and somthing that is shown is evidently not an $a$ priori truth. But this is only the first step towards understanding solipsism. The second step is to see that there is more than a similarity between my world and the world. The world is my world. This follows from the fact that both worlds consist of objects, together with the fact that the apparently fierce restriction that solipsism puts on the range of objects is not really a restriction at all, because the ego cannot be used as a reference point. 
But how much truth is there in solipsism? Now Wittgenstein is only concerned with solipsism based on the ego. His assessment of it is that it makes the good point that the limit of the world and of language is fixed by a certain range of objects. But by what range of objects? Here, according to him, the solipsist spoils his good point by trying to say what can only be shown. Now the realm of what can be said is the realm of contingent propositions. So the solipsist's error is to try to transfer his good point to the realm of contingent propositions. The way in which he tries to effect this transference is subtle. First he says that the world is his world. Then he treats his world as a receptacle with limits fixed not by its contents but by their relation to his ego. If this treatment of his world were possible, his original statement really would be contingently true, if true at all. For it would identify the macrocosm with an empirically specified microcosm. But, even if this reductive identification were intelligible in other ways, it fails because it is impossible to specify the microcosm empirically. The solipsist has the illusion of success in this impossible enterprise only because he supposes his ego to be a usable reference point. When he realises that it is not a usable refer ence point, he can still go on saying that the world is his world, but he must now mean this not as an identity statement which reduces the macrocosm to a specified microcosm, but rather as one which expands the microcosm to an unspecified macrocosm.

These are long words. The simple point on which Wittgenstein's assessment of solipsism rests is that the word "ego" is not the name of an identifiable objet, but something more like a variable. It is not exactly like a variable, because it cannot even take names as values. It is something more withdrawn, "a limit of the world - not a part of it" (5.641). If this point is to have the effect that he evidently thinks that it has - the expansion of the limit of "my world" until it coincides with the limit of the world - he cannot 
be identifying objects with any private type of thing, or, at least, if he does he cannot be treating their privacy as absolute. It is essential to my interpretation that he should not be concerned with phenomenologically based solipsism, or, at least, that if his discussion happens to apply to that type of solipsism, that will only be because the solipsist does not make any use of the fact that his objects are phenomenological, but relies on the ego as a reference point. In fact, both the Notebooks and the Tractatus provide my interpretation with all the support that it needs at this point, and the evidence has been ignored by many commentators not because it is tenuous, but because Wittgenstein's grounds for solipsism are unusual.

It is a corollary of my interpretation that Wittgenstein was not any kind of restrictive solipsist. Of course, he was a solipsist, but only because he took the theory in an unrestrictive way. On the other hand, he sympathised with the solipsist's tendency to transfer his thesis to the realm of contingent propositions. But he did not agree with it. There is a passage in the Notebooks in which he gives his own solipsistic tendency full rein: "What has history to do with me? Mine is the first and only world! I want to report how I found the world" etc. (2 September 1916). But he immediately notes down the corrective: "The philosophical self is not the human being, ... .etc". (the early version of the last paragraph of 5.641 , but with a difference, which I shall mention later).

It is, perhaps, not enough to argue that in the Note. books and the Tractatus the only kind of solipsism considered by Wittgenstein is solipsism based on the ego. This is certainly a fact, and, if it were not for this fact, he could not have treated "my world" as a receptacle with limits fixed by its contents, and the key would not have turned the lock. But we also need to know why he confined his attention to this type of solipsism, and whether there is any plausibility and interest in the movement of his thought 
from the critique of Russell's 1913 theory of the ego to his own theory about the limit of language.

Let us start from the thesis that the word "ego" is not the name of an identifiable object, but something more like a variable. Suppose that we tried to rewrite this thesis in the material mode. It would come out as a thesis about the nature of egos, or "subjects that think and entertain ideas" (5.631). Or rather, since the word "ego" cannot even take names as variables, it would come out as a thesis about the phenomenon of subjectivity - something like this: "There really is only one world soul, which I for preference call $m y$ soul and as which alone I conceive what I call the souls of others" (Notebooks, 23 May 1915).

The next entry for this day is: "The above remark gives the key for deciding the way in which solipsism is a truth". It might be thought that the phrase "The above remark" does not have the same reference that the phrase "This remark" has in Tractatus 5.62, and that the key is not the one that is mentioned there. But the first entry for the day, which immediately precedes the statement that "there really is only one world soul", is "The limits of my language mean the limits of my world", and this entry may well be the reference of the phrase "The above remark", as it may also be the reference of the phrase "This remark" in the Tractatus. In any case the key would be the same: both the world and my world are receptacles with limits fixed by their contents. My world may appear to be an empirically limited receptacle. But this is an illusion, because my world cannot be individuated through an ego. There really is only one world soul.

When Wittgenstein's thesis about the ego is expressed in this way in the material mode, it may be called "idealism". He himself calls it that in the passage in the Notebooks in which he recapitulates his remarks about solipsism and the ego: "This is the way I have travelled: Idealism singles men out from the world as unique, solipsism singles me 
alone out, and at last I see that I too belong with the rest of the world, and so on the one side nothing is left over, and on the other side, as unique, the world. In this way idealism leads to realism if it is strictly thought out" (15 October 1916). In the Tractatus he omits the first stage in his account of this journey, and makes it start from solipsism (5.64).

Nevertheless, it is worth asking what kind of idealism he meant when he called the thesis, that there is only one world soul, "idealism". The answer to this question ought to throw light on his unusual version of solipsism. For according to him, the two doctrines originate in the same kind of way.

We might conjeture that he meant some kind of post-Kantian idealism. But this cannot be right. For never in the Notebooks or in the Tractatus does he express even qual. ified agreement with the kind of idealism that restricts or tends to restrict the mind to knowledge of its own contents. It is true that he uses the language of 19th centruy idealism, and, in particular, the language of Schopenhauer. But he is putting new wine into old bottles, and he is characteristically reticent about its effect on them. His theory of representation is essentially realist. The mind consists of picturing facts (5.541-5.5421, and Letter to Russell dated 19 August 1919, Notebooks p. 129), but its knowledge is not restricted to them. If its knowledge did not reach beyond them, it could not have constructed them.

It is, at first, difficult to see how any kind of idealism could have developed out of this theory. But there is a clue to the development, and it is contained in the doctrine that "The world is all that is the case" (1). If all facts belong to the world, they are on the same level. But some are pictured facts and some are picturing facts, and when a mind, which is a series of picturing facts, tries to picture itself, it is likely to suffer from a persistent illusion. It will seem that behind the mirror of this mind's language there must 
be an individual focal point, the ego. This is not entirely wrong, because thinking requires a thinker. The illusion begins when the thinker is treated as an individual and yet not identified with the series of facts that constitute his physical and mental life. The way to dispel the illusion is to realise that on the one hand the ego does not belong to the world, and that, on the other, all facts, including those that constitute the thinker, do belong to it and are on the same level. So the world contains my picturing facts and yours, and an elephant's, if it has any. If we wish to bring in the ego, we should not show favouritism. There is no privileged set of picturing facts. Any set has a focal point, but no focal point can be individuated empirically. They all merge into the single focal point behind "the great mirror" (5.511). Idealism is mistaken when it "singles men out from the world as unique", and solipsism is equally mistaken when it "singles me alone out" (Notebooks, 15 October 1916).

One reason for accepting this interpretation of Wittgenstein's treatment of solipsism and realism in the Tractatus is that it is the only one that makes his connections of thought intelligible. Why else would he say that "the self of solipsism shrinks to a point without extension" (5.64)? But there is also some supporting evidence in the Notebooks. As has already been mentioned, the early version of the last paragraph of 5.641 occurs on 2 September 1916. But it is a slightly longer and more explicit version: "The philosophical self is not the human being, not the human body or the human soul with the psychological properties, but the metaphysical subject, the boundary (not a part) of the world. The human body, however, my body in particular, is a part of the world among others, among animals, plants, stones, etc., etc.". The extra point about the human body is picked up in the next two entries: "Whoever realises this will not want to procure a pre-eminent place for his own body or for the human body. He will regard humans and 
animals quite naively as objects which are similar and belong together." This must mean that anyone who realises that he, body and body-based mind, belongs to the world of facts, like any other identifiable thing, will no longer want to show solipsistic favouritism to his own body, or idealistic favouritism to all human bodies. The piece of favouritism that Wittgenstein means is the attempt to associate "the metaphysical subject" with one's own body, or with human bodies rather than with animals' bodies, or, more generally, with anything at all.

This interpretation receives some further confirmation from an obscure discussion of psycho-physical parallelism a few days later. "Now of course the question is why I have given a snake just this spirit. And the answer to this can only lie in the psycho-physical parallelism. If I were to look like the snake and to do what it does then I should be such-and such. The same with the elephant, with the fly, with the wasp" (15 October 1916). At this point he seems to change the direction of his thought. Instead of using "spirit" to mean something empirically discoverable, such as character, he begins to use it to mean "the metaphysical subjet". At least, this seems to be the only way of making sense of the next three entries: "But the question arises whether even here my body is not on the same level as that of the wasp and of the snake (and surely it is so), so that I have neither inferred from that of the wasp to mine [sc. spirit] nor from mine to that of the wasp. Is this the solution of the puzzle why men have always believed that there was one spirit common to the whole world? And in that case it would, of course, also be common to lifeless things too. This is the way I have travelled..." (already quoted).

The Tractatus omits this part of his itinerary. Perhaps the reason is that the interpretation of idealism is too farfetched. Or perhaps it is that it does not attribute sufficient importance to the mind. But the excursion in the Note- 
books has a certain importance. It corroborates the sugges. tion that the solipsism of the Tractatus is based on the ego. For the idealism of the Notebooks is based on the ego, and its is a parallel formation.

Wittgenstein's solipsism, based on an ego treated in the way that he treats it, is genuinely transcendental. A solipsism based on the assumption that all my objects are private would not have this character at all. Later, when Wittgenstein and some of the philosophers of the Vienna Circle explored the consequences of identifying objects with sensedata, the solipsism envisaged has a mixed character.

It would requiere another paper to trace that development and assess the relative importance of the two routes to solipsism. All that I hope to have achieved in this one is a demonstration of the coherence and power of Wittgenstein's critique of solipsism based on the ego. Certainly, he borrows the terminology and imagery of Schopenhauer. But the result is not a patchwork, because the ideas are his own, and a strong line of argument runs through them and connects them. In presenting the argument I started from $\mathrm{Ru}$ ssell's 1913 theory of the ego. If this seemed to put the emphasis in the wrong place, I hope that it has now been corrected. Russell's theory was clearly vulnerable to objections derived from Kant through Schopenhauer. The original element in Wittgenstein's discussion of that old controversy is the really fascinating way in which he connects it with his own theory of language. 
RESUMEN

Los enigmáticos pasajes 5.6-5.641 tienen una riqueza tal que dificulta la confianza en una interpretaación completa. El autor se limita por ello a seleccionar algunos puntos para mostrar un razonamiento independiente $\mathrm{y}$ original que los vincula.

Las restricciones solipsistas tienen dos consecuencias diferentes: limitan el conocimiento de verdades y la comprensión de significados. El solipsismo tradicional acentúa la primera y el solipsismo lingüístico la segunda. Ambas versiones se enfrentan, empero, a un problema formidable. ¿Cómo identificar el punto de referencia mismo?

Las características sobresalientes del tratamiento de Wittgenstein son cuatro. (I) Es una investigación del sujeto mismo o ego. (II) Explora las consecuencias del hecho de que el Ego no es un objeto de la experiencia (tesis de Hume). (III) Se ocupa especialmente de las consecuencias para el solipsismo lingüístico. (IV) El resultado de la investigación es que el solipsismo lingüístico hace una buena observación, pero de manera equivocada, ya que trata de decir lo que sólo puede mostrarse.

El autor sugiere que los últimos tres puntos son una crítica a la explicación del Ego proporcionada por Russell en: "On the Nature of Acquaintance".

Una dificultad de la tesis de Russell consistía en que conforme a sus principios empiristas el Ego tenía que ser, o bien una construcción lógica a partir de cosas de otro tipo, o bien similares a algún tipo de cosa de la que tengamos conocimiento directo. Russell no intentó el primer camino hasta 1918 y el Ego difícilmente satisfacía los requisitos para la segunda vía.

La crítica basada en (II) tiene una parte clara y otra oscura. En la parte clara se infiere del hecho de que el Ego no es un objeto de la experiencia, la conclusión de que no es identificable con independencia del campo de objetos considerado y, en consecuencia, la aparente restricción del solipsismo a las cosas existentes es una impostura. Para esta crítica Wittgenstein hace uso de una analogía de Schopenhauer (5.6331 y ss.). La parte oscura es la especificaión del campo de objetos.

La transcición de Wittgenstein al solipsismo es poco clara y parece hecha a la luz de sus diferencias con la teoría de la representación de Schopenhauer. De hecho hay dos interpretaciones (Hacker) rivales a la del autor sobre como se conectaba la teoría 
del Ego con el solipsismo. Una pretendería que el enunciado a priori indica que mis experiencias me pertenecen y no pueden pertenecer a otro. Se basa en el criterio de identidad numérica entre los objetos fenomenológicos de la experiencia y los de mi experien. cia. Esta interpretación se rechaza por cuatro razones. $1^{\circ}$ En el Tractatus Wittgenstein no se compromete con la idea de que los objetos son fenomenológicos. $2^{\circ}$ Aun así, en el Tractatus no se ve el paso del solipsismo al realismo (5.64). $3^{\circ}$ Tal enunciado a priori no está particularmente conectado con la teoría del Ego, pues sería relevante también para una teoría que lo tratase como construcción lógica. $4^{9}$ Esta interpretación pasa por alto la relevancia de la teoría de la representación de Wittgenstein.

En la segunda interpretación el enunciado a priori diría que si experimenta cualquier objeto entonces tal experiencia es mía. Mi posesión de la experiencia no se sigue de las propiedades de aquello que experimento. Esta interpretación tiene una falla, esta verdad a priori es un obstáculo sólo para la teoría de que yo soy un Ego puro identificable sólo a través de "mi" campo de objetos, precisamente la teoria contra la que se dirige Wittgenstein. Lo anterior hace preferible la argumentación del autor.

Queda por entender de qué manera suponía Wittgenstein que la teoría del Ego estaba conectada con el solipsismo. Si el campo de objetos limita las proposiciones que pueden comprenderse, habría que preguntarse si son objetos que están en el campo de una persona particular, o si esta restricción queda abolida al revelarse que el ego es un punto de referencia ficticio. Al no comprometerse Wittgenstein con la idea de que los objetos son fenomenológicos, no puede tratarse de este tipo de restricción. Los objetos básicos son los objetos de "mi mundo" (5.6), pero esto es restrictivo sólo si se identifica "mi" y en el Tractatus es un "yo filosófico" (5.641) que "no pertenece al mundo" (5.632). El solipsismo no es genuinamente restrictivo por usar un punto de referencia inútil.

Para tratar el punto (IV) hay que conectar la discusión del solipsismo con el resto del libro. ¿Qué es lo que sólo puede ser mostrado y por qué?

De 5.55 y ss. se sigue que no podemos determinar a priori el rango de objetos, lo único que "sabemos con bases puramente lógicas" es "que tiene que haber proposiciones elementales" y por tanto, objetos. ¿Sería entonces una cuestión empírica que haya tales o cuales objetos en el mundo? Parecería que si, puesto que "la realidad empírica está limitada por la totalidad de objetos" (5.5561), empero este límite no es empírico, ya que el rango de objetos fija también los límites de las proposiciones que pueden comprenderse y del mundo. En 5.61 se contesta la cuestión, la 
cosa que sólo puede mostrarse es que hay tales y cuales objetos, no es un enunciado empírico sino que está presupuesto por la existencia del lenguaje. Es una conclusión metafísica pero no cuasicientífica, ni a priori.

En 5.62 se dice: "Esta observación proporciona la clave para decidir la cuestión de en qué medida es el solipsismo una verdad." Si se refiere a 5.6 la clave consiste en que los contenidos de un receptáculo sólo pueden ser mostrados cuando es imposible darlos empíricamente puesto que ellos fijan los límites del receptáculo.

El segundo paso para entender el solipsismo era ver que hay más que una simple semejanza entre mi mundo y el mundo. Como ambos consisten de objetos y la restricción del solipsismo no es tal puesto que el Ego no puede ser usado como punto de referencia, se sigue que el mundo es mi mundo.

$Y$, ¿qué tan verdadero es el solipsismo? Es acertado mostrar que el límite del mundo y del lenguaje está fijado por un rango de objetos, pero al decirlo el solpsista entra al campo de las pro. posiciones contingentes tratando su mundo como un receptáculo con límites fijados por la relación con su Ego. El Ego, empero, es un punto de referencia inútil. Al decir que el mundo es su mundo, no deduce ya el macrocosmos a un microcosmos específico, sino que más bien expande al microcosmos a un macrocosmos especificado, El Ego es "un límite del mundo - no una parte de él (5.641).

El solipsismo de Wittgenstein no era restrictivo y aunque simpatizaba con la tendencia restrictiva del solipsista, no estaba de acuerdo con él (N.B. 2 sept. 1916).

La teoría de la representación de Wittgenstein es esencialmente realista; la mente consiste en hechos figuradores (5.541-5.54.21), pero su conocimiento no se restringe a ellos, pues de ser así no podría haberlos construido: "El mundo es todo lo que es el caso" (1), hechos figurados y hechos figuradores, y si la mente trata de figurarse a sí misma sufrirá una ilusión persistente. El pensador trata de individualizarse, pero sin identificarse con la serie de hechos que constituyen su vida física y mental. Para deshacerse de la ilusión hay que darse cuenta que el Ego no pertenece al mundo y que todos los hechos, incluyendo los que constituyen al pensador, pertenecen a él. Ningún conjunto de hechos figuradores tiene privilegio $y$ aunque tenga un punto focal, no puede ser individualizado empíricamente. Todos juntos se funden en un solo punto focal tras "el gran espejo" (5.511). Esta interpretación hace inteligible (5.64) y encuentra apoyo además en N. B. El solipsismo de Wittgenstein basado en el Ego es genuinamente trascendental, 
como no lo sería el que considera que todos mis objetos son privados.

El elemento original de Wittgenstein en su crítica al solipsismo de Russell es el modo fascinante en que conecta la vieja controversia con su propia teoría del lenguaje. 